\title{
Tourism potential analysis of the castles of Vinalopó, Spain: an opportunity for social and tourist development of cultural heritage
}

\author{
E. Rico Cánovas \\ Department of Regional Geographical Analysis and Physical Geography, \\ University of Alicante, Spain
}

\begin{abstract}
Within the overall framework of the renewal process of coastal tourist destinations, cultural heritage has frequently been used as a key argument for the introduction and development of strategies for the diversification and differentiation of the traditional tourist product based on sun and sand. This is the situation of the province of Alicante, identified with the Costa Blanca geotourism brand, where there are important economic issues that could contribute to the renewal of this coastal tourist destination. One of the most significant heritage values of this space consists of a series of medieval fortresses located along the axis of the Vinalopó River, which has acted since prehistoric times as a natural route from within the provincial mainland to the coast. It is precisely the argument of this historical, territorial and landscape content that has been used repeatedly in recent years to develop initiatives aimed at the creation of a tourist product, currently inexistent, based on the route of the castles of Vinalopó. This communication aims to analyse the degree of tourism potential of the fortresses located in the towns of Biar, Banyeres de Mariola, Sax, Villena, Novelda, Elda, Petrer and Elche, which constitute the core of municipalities where these medieval fortresses are located, finally pointing out some proposals for the creation of a heritage tourism product.
\end{abstract}

Keywords: renovation, consolidated tourist destinations, cultural heritage, Vinalopó Castles' route. 


\section{Introduction: renewal processes of consolidated coastal destinations}

Since tourism activity began in the area, the province of Alicante has been identified from the promotional perspective with the Costa Blanca tourism brand, which defines one of the most important beach destinations of the western Mediterranean. Its long track record in tourism is based on the existence of comparative advantages constituted by the traditional natural factors (excellent climatic conditions and extensive beaches), the development of an abundant supply of tourist facilities and its privileged position with respect to the real and potential demand markets. The characteristics mentioned make this space the area with the highest concentration of tourists and residents in the Valencian Community [1:170], which constitutes the downside to the positive benefits of the activity, that is, the generation of regional imbalances owing to the excessive density of occupation of the coastal and pre-coastal space [2] and which affect precisely the natural factors that act as the main attractions of the destination [3].

The enormous dynamism of international tourism scenario has a direct impact on the overall perception of the destinations by the demand and on the decision and selection of a destination by tourists. Currently, demand trends point to greater experimentation, activity and information on the part of the individual and give rise to the appearance of new destinations and tourism products [4]. The creation of new points of attraction or the reinvention of some traditional tourist destinations is a significant factor. These processes have commenced as a result of the activation of heritage resources that had been passive [5] to form a new cultural tourism supply that has triggered a renewed tourism dynamic, enormously attractive in the market, and which has already begun to reap results. Furthermore, tourist destinations are also undergoing changes that show their dynamism and evolution. There are possibilities of renewal and requalification of mature coastal tourism destinations via the implementation of new strategies [6-9]. One of the strategies is the strategy of diversification [6,7], based on the development of new tourism products that take as their cornerstone the natural and cultural resources located in the territory $[1,5]$. This systemic and territorial conception of tourism areas gives rise to a theoretical framework of analysis that is more closely adapted to the characteristic territorial component defining the tourism space [10].

The presence of new products based on heritage around the Costa Blanca would make it possible to correct the sun and sand monoculture that is predominant in the region, adapting better to the new market requirements imposed by the changes in demand [11]. This tourism space has a multitude of heritage resources of different classification that are not prepared for the requirements of the demand and visit. The fortresses of the river Vinalopó is a set of elements that could act as the main attraction in a new tourism product of a cultural nature for the Costa Blanca destination. 


\section{The castles of Vinalopó as an argument for the creation of a heritage tourism route}

The river Vinalopó is a historic highway which, from its source, passes through the towns of Bocairent (Valencia), Banyeres de Mariola, Villena, Sax, Elda, Novelda, Monforte del Cid and Elche (Alicante). This corridor is the setting for the mediaeval fortresses that would constitute the main attractions of the route. This historic highway has been especially important from prehistoric times, it was the main avenue for penetration of the peninsula from the coast and had constituted a fundamental channel of communication and human settlement. It offers sufficiently strong territorial, landscape, geographical, historical and cultural unity to become an important argument on which to base the creation of a tourism route.

Most of the fortresses that have been conserved are of Almohad origin (XIXIIc.) at the height of Muslim occupation in the province of Alicante [12]. This area was subsequently conquered by Christian troops and in the 13th century it was disputed by the Kingdom of Valencia (Crown of Aragón) and the Kingdom of Murcia (Crown of Castile) between Jaime I and Prince Alfonso of Castile. The dividing line that separated the two kingdoms was finally established in the Treaty of Almizra (1244) in the current municipality of Campo de Mirra, where the ruins of its castle are conserved. According to this treaty, the frontier is organised following the orographic line of the area that stretches between Biar and the Mediterranean, leaving for Aragón the mountainous districts and for Castile, the Alacantí district and the Vinalopó Valley. Therefore, this series of fortresses is a legacy of these histories of frontiers under constant vigilance by the enemy.

The castles of Vinalopó share practically the same architectural and constructional characteristics. Their large size corresponds to the function of a refuge for the population. The fortress is reduced to a rocky mass, to which access

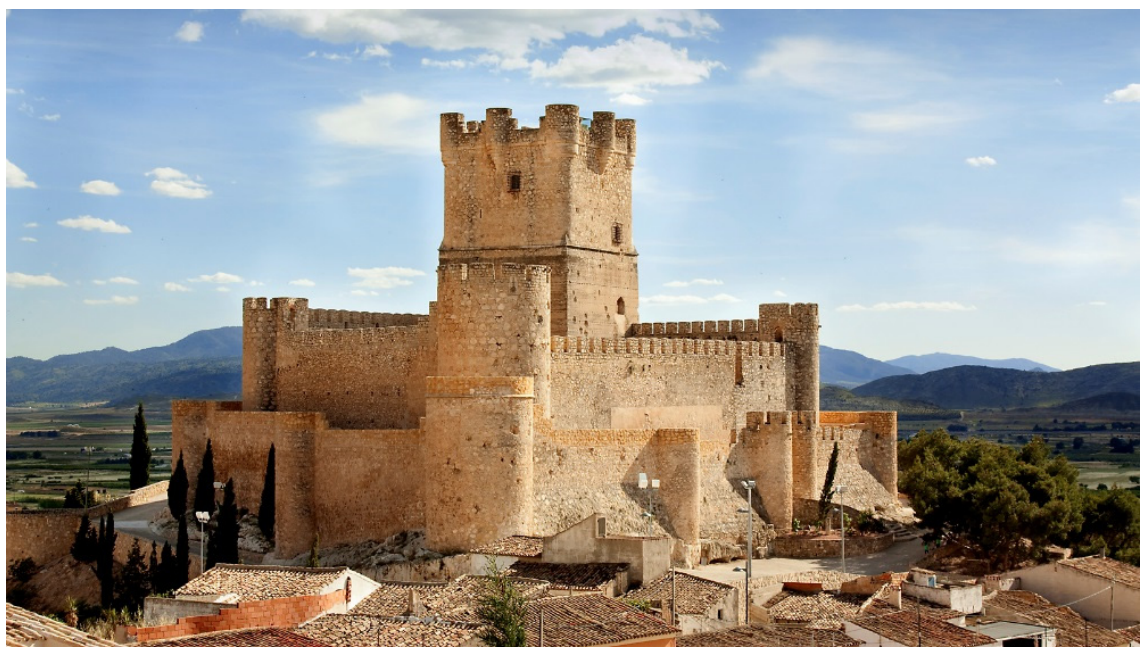

Figure 1: Castle of Villena. 


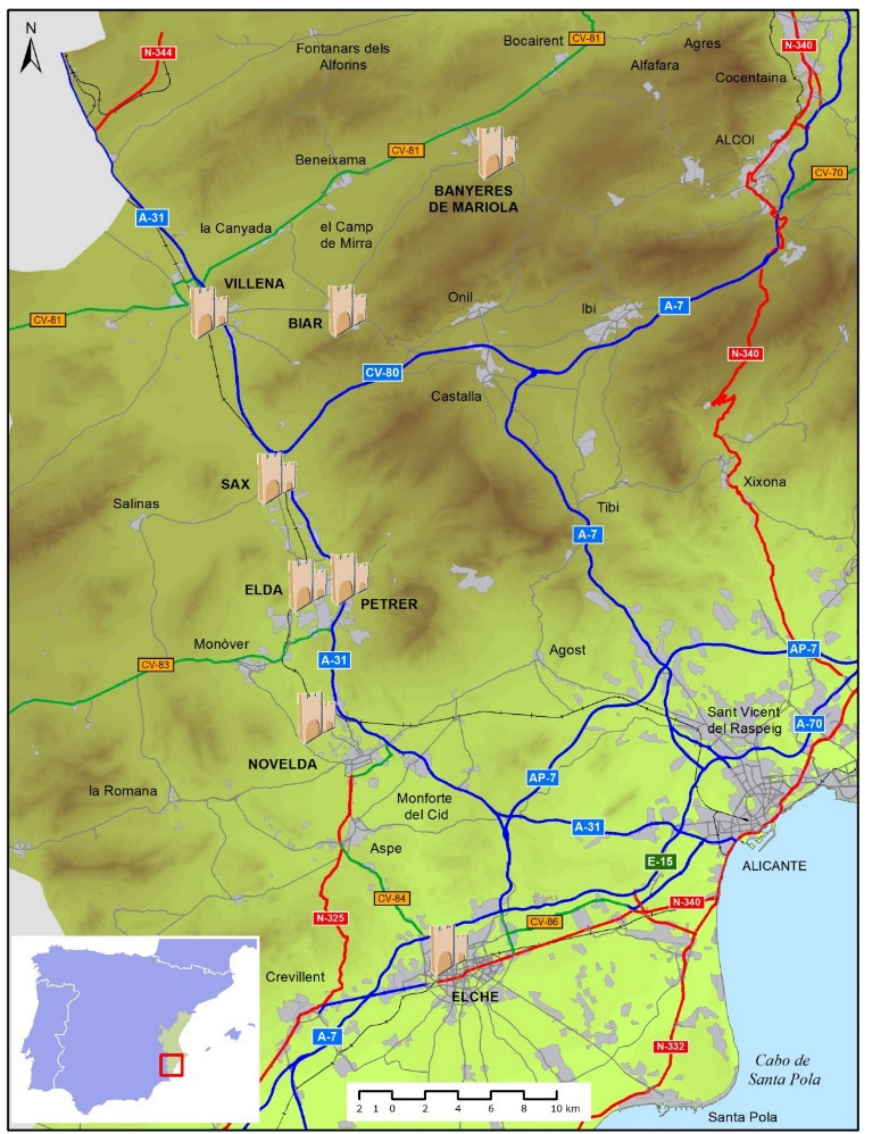

Figure 2: Location of the castles of the Vinalopó valley.

is complicated, protected on all sides by a cliff that serves as a natural defence. They are located high up on rugged terrain that is predisposed to facilitate defence. They present an open-air esplanade surrounded by a wall, separated by bastions or rectangular towers. The construction technique is generally rammed earth, consisting of walls built by compacting earth in a wooden frame that served as a form. This technique corresponds to the time of the building boom that took place in the Almohad era after 1145. The oldest parts of the castles of Biar, Villena, Novelda, Petrer, Sax and Banyeres date from this era. Prominent in all of these is the use of angled doors, barbicans and albarrana towers, separated from the rest of the structures or joined by means of a small easily destroyed bridge, elements that would constitute the last redoubt of resistance to the enemy.

The subsequent Christian conquest would involve the reinforcement of the strategic function of these castles, as fundamental frontier elements. It also entailed a substantial change in their functionality according to whether they belonged to one kingdom or the other since. The Crown of Aragón would provide 
the castles with a greater defensive capacity, whilst the Crown of Castile would cede them to the nobility as palaces. This fact led to a spatial adaptation of their precincts to the new uses as can be seen in the castles of Sax, Villena, Petrer, Novelda and the castle-palace of Elda. All would be subjected to major renovations after the appearance of gunpowder (1331) as a military element, which would lead to the overhaul of the constructional design of these fortresses.

It is fundamental to emphasise that they constitute a true communication system based on warnings and visuals alerts that allowed them to act more rapidly in the event of an enemy attack. It is also worth highlighting that the current castles are closely linked to the historical centres of the towns they protected. This fact has conditioned the physiognomy of these urban areas, creating a typical historic quarter with narrow streets and low houses, characteristic of mediaeval development (Biar, Villena and Banyeres).

The evidence based on historical, territorial, architectural and landscape aspects of these heritage elements sustains the proposal for their transformation into a tourism route. For this reason, this study analyses the degree of tourism functionality of the castles of Banyeres de Mariola, Biar, Villena, Sax, Novelda, Elda, Petrer and Elche.

\section{Analysis of the tourism functionality of the castles of Vinalopó: accessibility, tourist facilities and services}

Other important aspects have been analysed from the perspective of the enhancement of heritage resources for tourism and recreational use. For this purpose, a series of favourable features has been taken into account regarding the characteristics of each fortress that indicate their degree of tourism functionality. These aspects refer to the level of attraction, internal and external accessibility, the availability and usefulness of the signposting, and the existing information media and tourist services.

Thus, the majority of the castles present a high degree of attractiveness, constituting attractions of great interest, prominent in the sphere of the municipality and the district. This is due to the fact that practically all the heritage elements have been subjected to restoration processes at some time [12].

The analysis of accessibility was considered from the point of view of physical and intellectual accessibility. The first of these refers to the location of the tourism resources in relationship with the main roads and means of communication of the municipalities involved as well as internal accessibility. This is related with the different possibilities of access to each castle in question, on the basis of the tourist signposting in place in the municipalities and the equipment prepared to receive the visitors.

The issue of accessibility also bears a direct relationship with the opening hours of the main resources. In most cases compliance with the established opening hours depends to a greater or lesser extent on the presence of municipal personnel (town hall, local museums and tourist information offices). Sometimes opening hours are limited to working days (Monday to Friday) and the tourism resource is 
closed on bank holidays. At present, only the castle of Elda is closed to the public owing to the renovation work underway in the fortress.

Internal accessibility refers to access and mobility inside the castle. In the majority of cases, it was observed that accessibility is good or fair although the actual structure of the fortresses (steep slopes, stairs, uneven floor) and the lack of lighting in some areas hinder access by the visitor and the normal progress of the visit. In all cases access is impossible for visitors with impaired mobility.

The analysis of the tourist services and facilities is directly related with the concept of intellectual accessibility. This must be considered a priority action in the process of enhancing the cultural heritage since it involves opening a heritage resource and presenting it to the public with the aim of its being understood and valued in order to contribute to an adequate social use and, therefore, to its conservation. Thus, it is necessary to understand that the public is by nature very diverse and varied, with different levels of education and interests, and tools are therefore required to facilitate the cultural understanding of a resource through the interpretation (guided tours and panels, for example) [13, 14].

For this reason, the study analysed the availability of informative elements that could be used by the visitor, such as information panels inside and outside the resource and the type of information offered, as well as the existence of models, interactive points and other informative elements and activities such as guided tours and thematic tours given by actors.

It has been ascertained from the direct observation of the information media that, in general, they respond to the usual characteristics such as the existence of excessively long texts, scientific language that does not facilitate reading or understanding and their distribution normally corresponds to the available space.

Another interesting aspect brought to light by the social enhancement of the fortress in question is the degree of use of the resource, as a place for representation, for use as a museum or for visits by tourists. This approach by the local community to the heritage resource contributes to their awareness and valuing of their own resources and helps support the claim for maintenance and conservation of the heritage elements as iconic symbols of the local community. In the case of Banyeres, the castle hosts the Museu de la Festa, and that of Petrer acts as a centre for various events related with the local fiestas and acts of protocol for the local authorities. At this castle the cave dwellings of the castle wall, opened to the public in 2009, have increased the heritage value of the visit to the fortress. The museum contents of this ethnological space strengthen the discourse regarding the social role played by the castle since its construction in sheltering and protecting the population.

With regard to the availability of tourist facilities an exceptional case compared to the other castles of the Vinalopó district is that of Villena, where a Visitors' Centre has been created at the site of the castle itself. It also entailed the urban and social redevelopment of this area, one of the most degraded spaces of the historic centre of Villena in recent decades. The availability of facilities at the resource itself is another of the aspects analysed. Thus, the castle of La Mola (Novelda) has toilets, rest areas, shady areas and a point of sale for drinks. 
Table 1 shows the results of the functionality of the castles of Vinalopó analysis (1-Biar. 2-Banyeres de Mariola, 3-Sax, 4-Villena, 5-Novelda, 6-Elda, 7-Petrer, 8Elche).

Table 1: Analysis of the tourism functionality of the castles of Vinalopó.

\begin{tabular}{|c|c|c|c|c|c|c|c|c|}
\hline ASPECTS & 1 & 2 & 3 & 4 & 5 & 6 & 7 & 8 \\
\hline ATTRACTIVENESS & $\mathrm{X}$ & $\mathrm{X}$ & $\mathrm{X}$ & $\mathrm{X}$ & $\mathrm{X}$ & $\mathrm{X}$ & $\mathrm{X}$ & $\mathrm{X}$ \\
\hline \multicolumn{9}{|l|}{ ACCESSIBILITY } \\
\hline \multicolumn{9}{|l|}{ Physical } \\
\hline Vehicle traffic & $\mathrm{X}$ & & & $\mathrm{X}$ & $\mathrm{X}$ & & $\mathrm{X}$ & $\mathrm{X}$ \\
\hline Parking & $\mathrm{X}$ & & & $\mathrm{X}$ & $\mathrm{X}$ & & $\mathrm{X}$ & $\mathrm{X}$ \\
\hline Pedestrian & $\mathrm{X}$ & $X$ & $\mathrm{X}$ & $\mathrm{X}$ & & & $\mathrm{X}$ & $\mathrm{X}$ \\
\hline Opening hours & $\mathrm{X}$ & $\mathrm{X}$ & $\mathrm{X}$ & $\mathrm{X}$ & $\mathrm{X}$ & & $\mathrm{X}$ & $\mathrm{X}$ \\
\hline \multicolumn{9}{|c|}{ Intellectual: tourist services and facilities } \\
\hline Information panels & $\mathrm{X}$ & $\mathrm{X}$ & $\mathrm{X}$ & $\mathrm{X}$ & $\mathrm{X}$ & & $\mathrm{X}$ & $\mathrm{X}$ \\
\hline Audio & $\mathrm{X}$ & & & & & & & \\
\hline Guided tours & & $\mathrm{X}$ & $\begin{array}{c}\mathrm{X} \\
\text { Sundays }\end{array}$ & $\mathrm{X}$ & $\mathrm{X}$ & & $\mathrm{X}$ & \\
\hline QR codes & $\mathrm{X}$ & $\mathrm{X}$ & $\mathrm{X}$ & $\mathrm{X}$ & $\mathrm{X}$ & $\mathrm{X}$ & $\mathrm{X}$ & $\mathrm{X}$ \\
\hline SOCIAL ENHANCEMENT & & $\mathrm{X}$ & & $\mathrm{X}$ & & & $\mathrm{X}$ & $\Lambda$ \\
\hline INTERNAL MOBILITY & - & - & & - & - & - & - & - \\
\hline
\end{tabular}

As can be seen, the results with regard to tourism functionality of the castles of Vinalopó vary greatly. The strengths would be the positive issues in need of strengthening and improvement for the purpose of creating a tourism product. The weaknesses, on the other hand, comprise the features that would need to be reduced as much as possible in order to contribute to enhancing the value of the positive characteristics listed.

\section{Proposal for the creation of a tourism product club for the castles of Vinalopó: weighing up the initiatives}

As can be seen, the degree of tourism functionality of the castles of Vinalopó presents some weaknesses that must be corrected with the objective of generating a new tourism product in the form of a thematic route. However, the existence of tourism resources, in this case the fortresses analysed, is not enough to attract visitors. It is fundamental to prepare and transform these tourism resources and combine them with tangible and intangible benefits to offer them to tourists, who will then be able to enjoy a recreational experience in the region of the Costa Blanca.

- To connect the tourism resources with the supply (accommodation and restaurants), the demand (tourists) and the tourism services (brokering companies, transport, guided tours, tourist activities, etc.). 
- The new tourism product must include improving the physical and intellectual accessibility.

- To consider a homogeneous system of signposting and tourist information for the resources and towns included in this product.

- To include companies that offer tourist services and activities in relationship with this route, as well as specialised training for tour guides.

- Each fortress should develop a specific theme within the route, from all the possible topics that could be proposed (military strategy, architecture, daily life, frontier stories, significant characters, etc.)

- To design an overall promotion and marketing plan that would include actions for dissemination of the existence of the product as well as merchandising.

- To develop a technical unit to centralise the control and management of the route.

- To create the Tourism Product Club of the Castles of the Vinalopó valley, on the basis of the strengthening of synergies, collaboration between members, efficiency in decision-making and a long-term working horizon.

Some initiatives have already been introduced. However, it is not possible to affirm that a real tourist route exists, since the proposals put forward previously are still far from being developed. Therefore, despite the opportunity represented by these heritage elements for the development of their recreational and tourism function, reality shows that it is still necessary to join forces and share objectives for action, and to abandon the local scale as the only scope of work.

\section{References}

[1] Capedpón, M. El papel de los parques naturales como elementos de diversificación en el marco de la renovación de los destinos turísticos consolidados. Online. http://rua.ua.es/dspace/handle/10045/36498

[2] Obiol, E. \& Pitarch, M.D., El litoral turístico valenciano. Intereses y controversias en un entorno tensionado por el residencialismo. Boletín de la Asociación de Geógrafos Españoles, 56, pp. 177-200, 2011.

[3] Vera, J. F. López Palomeque, F.; Marchena Gómez, M.; Anton Clavé, S., Análisis territorial del turismo y planificación de destinos turísticos, Tirant Lo Blanch: Valencia, pp. 473, 2011.

[4] Anton, S. \& González, F., La naturaleza del turista. De la turismofobia a la construcción social del espacio turístico. A propósito del turismo. La construcción social del espacio turístico. Editorial UOC: Barcelona, pp. 1133, 2008.

[5] Navalón, R. \& Rico, E., Renovación de destinos litorales maduros a partir del patrimonio cultural: Plan Costa Blanca Cultura (Chapter 14). Renovación y reestructuración de destinos turísticos en áreas costeras; eds. J. F. Vera \& I. Rodríguez, Colección Desarrollo Territorial, Universitat de València: Valencia, pp. 323-345, 2012.

[6] Agarwal, S., La reconversión del turismo costero. El ciclo de vida del destino turístico costero. Annals of Tourism Research, 4 (1), pp. 1-36, 2002. 
[7] Vera, J.F. \& Baños, C., Renovación y reestructuración de los destinos turísticos consolidados del litoral: las prácticas recreativas en la evolución del espacio turístico. Boletín de la Asociación de Geógrafos Españoles, 53, pp. 329-353, 2010.

[8] Bramwell, B., Mass tourism, diversification and sustainability in Southern Europe's coastal regional. Coastal mass tourism. Diversification and sustainable development in Southern Europe, ed. B. Bramwell, Channel View Publications: Clevedon, pp. 1-31, 2004.

[9] Anton, S., De los procesos de diversificación y cualificación a los productos turísticos emergentes. Cambios y oportunidades en la dinámica reciente del turismo litoral, Papeles de Economía Española, 102, pp. 316-333, 2005.

[10] Haywood, M., Legitimising the TALC as a theory of development and change. The tourism area life cycle. Applications and modifications, ed. R. Butler, vol II, Channel View Publications: Clevedon, pp. 29-43, 2006.

[11] Rico, E., El patrimonio cultural como argumento para la renovación de destinos turísticos consolidados del litoral en la provincia de Alicante. Online: http://rua.ua.es/dspace/handle/10045/40780, 2014.

[12] Segura, G. \& Simón, J. L., Castillos y torres en el Vinalopó, Centre d'Estudis Locals del Vinalopó: Petrer, pp. 89, 2001, 242, 2014.

[13] Espinosa, A., La accesibilidad física e intelectual de todo tipo de público al patrimonio cultural (I, II). Boletín de Interpretación, 6, Asociación para la Interpretación del Patrimonio, pp. 13-15, 2002.

[14] Morales, J., El sentido y la metodología de la interpretación del patrimonio, La comunicación global del patrimonio cultural, coord. S. Mateos, Ediciones Trea: Gijón, pp. 53-75, 2008. 